\title{
Sosialisasi Prosedur Pelaksanaan Bakti Sosial Bibir Sumbing dan Lelangit di Daerah Terpencil di Indonesia
}

\section{Reza Al Fessi*1, R. Aries Muharram², Indra Mulyawan'3 , Prasiddha Mahardhika4, Ameliana Nuraeni ${ }^{5}$, Achmad Zam Zam Aghasy 6}

\author{
1,2,3,4,5 Departemen Bedah Mulut dan Maksilofasial, Fakultas Kedokteran Gigi, Universitas Airlangga, \\ Indonesia \\ 6Indonesian Health Collaboration and Innovation Institute (IHCI Institute), Indonesia \\ *e-mail: $\underline{\text { reza.al.fessi@fkg.unair.ac.id }}{ }^{1}$ aries-m@fkg.unair.ac.id ${ }^{2}{ }_{\text {indramulyawan@fkg.unair.ac.id }{ }^{3}}{ }_{2}$ \\ prasiddha.mahardhika.el-2018@fkg.unair.ac.id ${ }^{4}$, ameliana.nuraeni-2020@fkg.unair.ac.id ${ }^{5}$, aghasy@ihci- \\ institute.net $^{6}$
}

\begin{abstract}
Abstrak
Persentase bibir sumbing dan lelangit di Indonesia menduduki peringkat ketujuh di Asia Tenggara, yaitu 20,4\%. Kesenjangan akses pelayanan kesehatan di daerah terpencil tersebut merupakan alasan kuat bagi kami untuk bergerak memberikan layanan bakti sosial bibir sumbing dan lelangit bagi masyarakat Indonesia di seluruh pelosok negeri, terlebih saat ini kondisi di lapangan dihadapkan oleh adanya pandemi COVID-19 yang membuat beberapa kegiatan bakti sosial di daerah terpencil tertunda. Sosialisasi ini bertujuan untuk transfer ilmu dan mengetahui gambaran wawasan peserta mengenai utilisasi bakti sosial operasi bibir sumbing dan lelangit di daerah terpencil di Indonesia. Metode yang digunakan adalah webinar terkait utilisasi bakti sosial operasi bibir sumbing dan lelangit di daerah yang diikuti oleh 54 peserta. Pengumpulan data dengan cara mengisi google form secara daring dilakukan dalam bentuk pre-test dan post-test, kemudian dianalisis dengan uji Paired sample t test dengan tingkat kemaknaan 5\%. Hasil kegiatan ini menunjukkan terdapat pengaruh dari penyelenggaraan sosialisasi melalui webinar mengenai utilisasi bakti sosial bibir sumbing dan lelangit di daerah terpencil dalam meningkatkan wawasan peserta webinar.
\end{abstract}

Kata kunci: Bakti Sosial, Bibir Sumbing dan Lelangit, Utilisasi

\begin{abstract}
The percentage of cleft lip and tenderness in Indonesia ranks seventh in Southeast Asia, which is 20.4\%. The gap in access to health services in remote areas is a strong reason for us to move to provide cleft lip and auction social services for Indonesian people throughout the country, especially now that conditions on the ground are faced with the COVID-19 pandemic which has led to several social service activities. in remote areas is delayed. This socialization aims to transfer knowledge and gain insight into participants' insights regarding the utilization of social services for cleft lip and Auction surgery in remote areas in Indonesia. The method used is a webinar related to the utilization of social services for cleft lip surgery and an auction in the area which was attended by 54 participants. Data collection by filling out google forms online was carried out in the form of pre-test and post-test, then analyzed by Paired sample t-test with a significance level of $5 \%$. The results of this activity indicate that there is an influence from organizing socialization through webinars regarding the utilization of cleft lip and auction social services in remote areas in increasing the insight of webinar participants.
\end{abstract}

Keywords: Cleft Lip and Tenderness, Social Service, Utilization

\section{PENDAHULUAN}

Persentase bibir sumbing dan lelangit di Indonesia menduduki peringkat ketujuh di Asia Tenggara, yaitu $20,4 \%$ salah satunya adalah Provinsi Nusa Tenggara yang memiliki angka kejadian bibir sumbing dan lelangit yang cukup tinggi di Indonesia. Dalam kaitan dengan kelahiran per tahun, prevalensi bayi lahir dengan bibir sumbing dan lelangit ditemukan semakin tinggi yaitu lebih dari 8.900 bayi lahir dengan bibir sumbing dan lelangit per tahun(Kemenkes RI, 2018). Bibir sumbing dan lelangit hanya dapat ditangani dengan tindakan operasi bibir sumbing dan lelangit (Tollefson et al., 2015). Rumah Sakit Gigi dan Mulut Universitas Airlangga (RSGM UNAIR) telah melaksanakan bakti sosial operasi bibir sumbing dan lelangit di daerah terpencil 
sejak tahun 2008. Kesenjangan akses pelayanan kesehatan di daerah terpencil tersebut merupakan alasan kuat bagi kami untuk bergerak memberikan layanan bakti sosial bibir sumbing dan lelangit bagi masyarakat Indonesia di seluruh pelosok negeri, terlebih saat ini kondisi di lapangan dihadapkan oleh adanya pandemi COVID-19 yang membuat beberapa kegiatan bakti sosial di daerah terpencil tertunda.

Personil yang terlibat bakti sosial adalah terdiri tenaga kesehatan dan tenaga non kesehatan. Dari kelompok tenaga kesehatan tersebut diantaranya termasuk profesi Dokter Gigi Spesialis Bedah Mulut dan Maksilofasial (SpBM) dan Dokter Gigi Residen Program Pendidikan Dokter Gigi Spesialis Bedah Mulut dan Maksilofasial (PPDGS BMM). Tenaga kesehatan tersebut mempunyai kewajiban untuk pengabdian masyarakat sesuai dengan aturan Kemenristekdikti (Kemenristekdikti, 2015). Adapun pengabdian masyarakat berupa bakti sosial operasi bibir sumbing dan lelangit di daerah terpencil memerlukan pedoman standar utilisasi pelaksanaan, untuk mendukung SOP Pelayanan Medis dan Pedoman Nasional Pelayanan Kedokteran (PNPK) Tatalaksana Bibir Sumbing dan Lelangit (Kemenkes RI, 2019).

Pada kondisi pandemi ini, tenaga kesehatan mengalami kendala dalam pelaksanaan pengabdian masyarakat secara tatap muka. Meskipun kondisi pandemi, kegiatan pengabdian masyarakat tetap harus dilaksanakan agar tidak terjadi kesenjangan pengetahuan, sehingga dilakukan sosialisasi prosedur pelaksanaan bakti sosial menggunakan media informasi berbasis digital(Ciasullo et al., 2021). Sosialisasi bertujuan sebagai media penyampaian informasi, media pembelajaran, dan sebagai sarana pendidikan(Novalia et al., 2021). Dalam hal ini media transfer ilmu menggunakan sebuah buku panduan yang berisikan standar utilisasi pelaksaan bakti sosial bibir sumbing dan lelangit. Hal inilah yang menjadi dasar bagi tim pengabdian masyarakat untuk melakukan sosialisasi kepada Residen PPDGS BMM tentang aspek utilisasi bakti sosial bibir sumbing dan lelangit di daerah terpencil melalui forum webinar. Sosialisasi ini bertujuan untuk transfer ilmu dan mengetahui gambaran wawasan peserta mengenai utilisasi bakti sosial operasi bibir sumbing dan lelangit di daerah terpencil.

\section{METODE}

Kegiatan ini merupakan sosialisasi yang nantinya didapatkan data deskriptif dengan pendekatan kuantitatif yang bertujuan untuk ditetapkan sebagai media penyampaian informasi, media pembelajaran, dan sebagai sarana Pendidikan yang dinilai efektif. Sosialisasi dilakukan secara daring pada bulan September 2021, bertempat di Surabaya. Populasi dalam kegiatan ini adalah seluruh residen PPDGS Bedah Mulut dan Maksilofasial Universitas Airlangga. Subjek sosialisasi sejumlah 54 residen yang dipilih dengan proportionate random sampling yaitu pengambilan sampel anggota populasi dilakukan dengan memperhatikan proporsi dalam populasi tersebut dengan kriteria inklusi yaitu seluruh residen PPDGS Bedah Mulut dan Maksilofasial Universitas Airlangga aktif dan sudah mengerjakan pre-test, post-test dan mendapatkan pemaparan materi utilisasi bakti sosial bibir sumbing dan lelangit di daerah terpencil. Kriteria eksklusi residen PPDGS BMM Universitas Airlangga yang tidak kooperatif.

Instrumen yang digunakan adalah kuesioner dan telah dilakukan uji validitas dan reliabilitas. Data hasil penelitian diolah dengan uji Paired sample t test dengan tingkat kemaknaan 5\%. Uji Paired sample t test digunakan untuk mengetahui hubungan antara variabel bebas dengan variabel terikat. Metode pengumpulan data dilakukan dengan cara mengisi google form secara daring dilakukan dalam bentuk pre-test dan post-test. Sebelum melaksanakan post-test residen mendapatkan pemaparan materi terlebih dahulu. Semua data yang terkumpul kemudian dikaji ulang dan dilakukan proses pengolahan data dengan bantuan SPSS.

\section{HASIL DAN PEMBAHASAN}

Kegiatan sosialisasi ini pertama dilakukan FGD antara stakeholder yang diikuti oleh perwakilan dari RSKGMP Universitas Airlangga, Departemen Bedah Mulut dan Maksilofasial 
Kedokteran Gigi Universitas Airlangga serta Rumah Sakit Jejaring dalam rangka untuk mempersiapkan standar utilisasi pelaksanaan kegiatan sosialisasi.

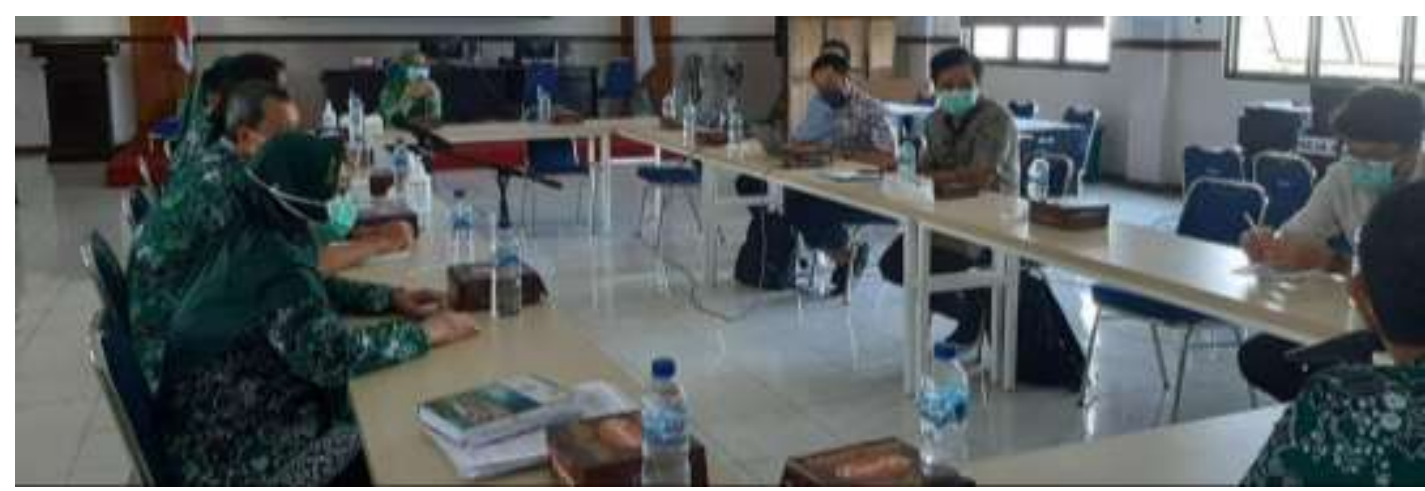

Gambar 1. FGD Persiapan Pengabdian Masyarakat

Kegiatan selanjutnya adalah sosialisasi pelaksanaan bakti sosial bibir sumbing dan lelangit di daerah terpencil didapatkan hasil mayoritas responden berusia $>26$ tahun yaitu sebanyak 49 (90.7\%) responden. Mayoritas responden yang ikut serta dalam kegiatan ini adalah dengan jenis kelamin laki-laki yaitu sebanyak 31 (57.4\%) responden. Pendidikan tertinggi responden adalah S1 Pendidikan Kedokteran Gigi yaitu 51 (94.4\%) responden. Mayoritas pekerjaan tertinggi adalah Dokter Gigi Praktisi yaitu sebanyak 31 (57.4\%) responden. Mayoritas responden pernah mengikuti bakti sosial bibir sumbing yaitu sebanyak 33 (61.1\%) responden.

Hasil analisis rerata skor pre test dan post tes responden mengenai utilisasi bakti sosial bibir sumbing dan lelangit:

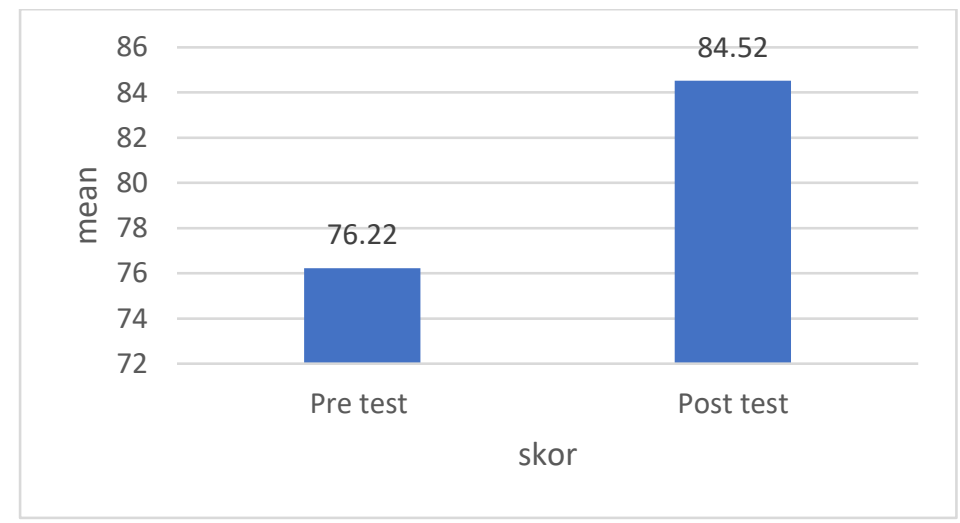

Gambar 2. Nilai rerata skor pre tes dan post tes

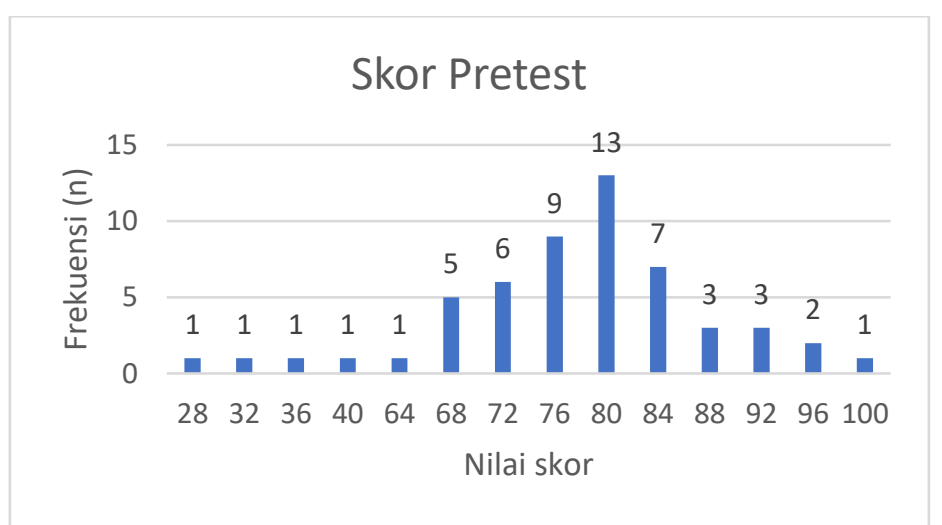

Gambar 3. Skor pre test 


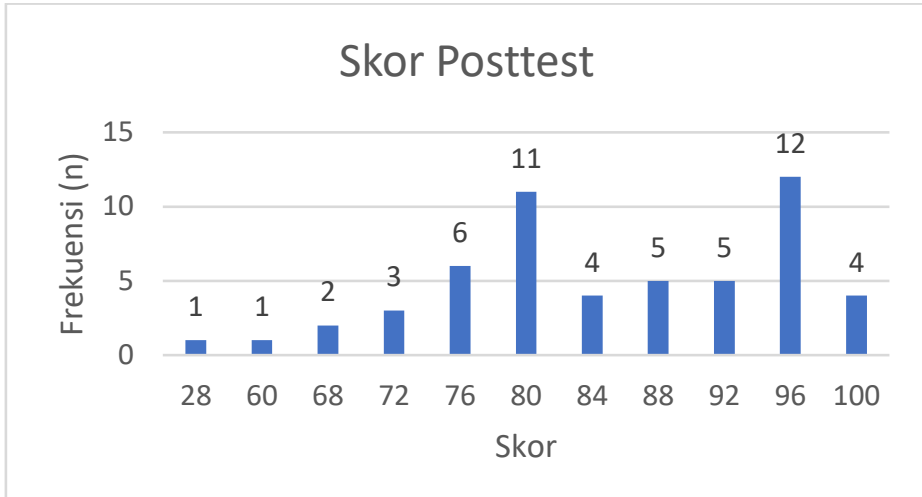

Gambar 4. Skor post test

Berdasarkan Gambar 2. Nilai rerata skor responden tertinggi adalah pada skor post test yaitu 84.52 sedangkan pada nilai rerata responden pre test yaitu 76.22. Skor pretest terbanyak dengan nilai 80 yaitu sebanyak 13 (24.1\%) responden seperti pada Gambar 3, sedangkan pada nilai pre test 100 hanya sebanyak $1(1.9 \%)$ responden. Kemudian, skor pretest terbanyak dengan nilai 96 yaitu sebanyak 12 (22.2\%) responden seperti pada Gambar 4.

Tabel 1. Peningkatan Wawasan Responden

\begin{tabular}{lcc}
\hline \multicolumn{1}{c}{ Kategori Wawasan } & Frekuensi (n) & Persentase \\
\hline Di atas rata-rata & 30 & 55.6 \\
Dibawah rata-rata & 24 & 44.4 \\
\hline
\end{tabular}

Berdasarkan Tabel 1. Hasil dari peningkatan wawasan dapat dilihat bahwa peningkatan wawasan di atas rata-rata adalah sebanyak 30 (55.6\%) responden sedangkan peningkatan wawasan dibawah rata-rata adalah sebanyak 24 (44.4\%) responden.

Tabel 2. Tabulasi silang peningkatan wawasan dengan usia responden

\begin{tabular}{|c|c|c|c|}
\hline \multirow{3}{*}{ Usia } & \multicolumn{2}{|c|}{ Peningkatan Wawasan } & \multirow{2}{*}{ Total } \\
\hline & Di atas rata-rata & Dibawah rata-rata & \\
\hline & n (\%) & n (\%) & n (\%) \\
\hline$\leq 26$ tahun & $3(5.6 \%)$ & $2(3.7 \%)$ & $5(9.3 \%)$ \\
\hline$>26$ tahun & $27(50 \%)$ & $22(40.7 \%)$ & $49(90.7 \%)$ \\
\hline Total & $30(55.6 \%)$ & $24(44.4 \%)$ & $54(100 \%)$ \\
\hline
\end{tabular}

Hasil tabel di atas menunjukkan bahwa mayoritas usia yang mengalami peningkatan wawasan adalah usia $>26$ tahun pada kategori peningkatan wawasan di atas rata-rata yaitu 27 (50\%) responden sedangkan terendah pada responden dengan usia $\leq 26$ tahun dengan kategori wawasan di atas rata-rata yaitu $3(5.6 \%)$ responden.

Tabel 3. Tabulasi silang peningkatan wawasan dengan jenis kelamin

\begin{tabular}{|c|c|c|c|}
\hline \multirow{3}{*}{ Jenis kelamin } & \multicolumn{2}{|c|}{ Peningkatan Wawasan } & \multirow{2}{*}{ Total } \\
\hline & Di atas rata-rata & Dibawah rata-rata & \\
\hline & n (\%) & n (\%) & n (\%) \\
\hline Laki-laki & $15(27.8 \%)$ & $16(29.6 \%)$ & $31(57.4 \%)$ \\
\hline Perempuan & $15(27.8 \%)$ & $8(14.8 \%)$ & $23(42.6 \%)$ \\
\hline Total & $30(55.6 \%)$ & $24(44.4 \%)$ & $54(100 \%)$ \\
\hline
\end{tabular}

Berdasarkan Tabel 3 menunjukkan bahwa peningkatan wawasan tertinggi pada jenis kelamin laki-laki dengan kategori peningkatan wawasan dibawah rata-rata yaitu 16 (29.6\%) responden sedangkan terendah pada jenis kelamin perempuan dengan kategori peningkatan wawasan dibawah rata-rata yaitu $8(14.8 \%)$ responden. 
Tabel 4. Tabulasi silang peningkatan wawasan dengan Pekerjaan

\begin{tabular}{lccc}
\hline \multirow{2}{*}{ Pekerjaan } & \multicolumn{2}{c}{ Peningkatan Wawasan } & \multirow{2}{*}{ Total } \\
\cline { 2 - 3 } & Di atas rata-rata & Dibawah rata-rata & \\
\cline { 2 - 3 } & n (\%) & n (\%) & n (\%) \\
\hline Dokter Gigi PNS & $1(1.9 \%)$ & $0.0 \%$ & $1(1.9 \%)$ \\
Dokter Gigi Praktisi & $14(25.9 \%)$ & $17(31.5 \%)$ & $31(57.4 \%)$ \\
Dokter Gigi Tentara & $3(5.6 \%)$ & $3(5.6 \%)$ & $6(11.1 \%)$ \\
Dosen & $2(3.7 \%)$ & $1(1.9 \%)$ & $3(5.6 \%)$ \\
PNS & $2(3.7 \%)$ & $0(0.0 \%)$ & $2(3.7 \%)$ \\
PPDGS & $8(14.8 \%)$ & $3(5.6 \%)$ & $11(20.4 \%)$ \\
Total & $55.6 \%$ & $44.4 \%$ & $100.0 \%$ \\
\hline
\end{tabular}

Hasil di atas menunjukkan bahwa peningkatan wawasan mayoritas pada pekerjaan dokter gigi praktisi dengan peningkatan wawasan dibawah rata-rata yaitu sebanyak 17 (31.5\%) responden sedangkan terendah pada pekerjaan Dokter gigi PNS dengan peningkatan wawasan di atas rata-rata dan Dosen dengan peningkatan wawasan dibawah rata-rata yaitu sebanyak 1 $(1.9 \%)$ responden.

Tabel 5. Tabulasi silang peningkatan wawasan dengan pengalaman Bakti Sosial Bibir Sumbing

\begin{tabular}{lccc}
\hline \multirow{2}{*}{ Bakti Sosial Bibir Sumbing } & \multicolumn{2}{c}{ Peningkatan Wawasan } & \multirow{2}{*}{ Total } \\
\cline { 2 - 3 } & Di atas rata-rata & Dibawah rata-rata & \\
\cline { 2 - 4 } & $\mathbf{n ~ ( \% )}$ & $\mathbf{n ~ ( \% )}$ & n (\%) \\
\hline Belum pernah & $10(18.5 \%)$ & $11(20.4 \%)$ & $21(38.9 \%)$ \\
Pernah & $20(37.0 \%)$ & $13(24.1 \%)$ & $33(61.1 \%)$ \\
Total & $30(55.6 \%)$ & $24(44.4 \%)$ & $54(100.0 \%)$ \\
\hline
\end{tabular}

Berdasarkan Tabel 5 menunjukkan bahwa peningkatan wawasan tertinggi pada responden yang pernah ikut serta bakti sosial dengan peningkatan wawasan di atas rata-rata sebanyak $20(37 \%)$ responden sedangkan terendah pada responden yang belum pernah ikut serta dalam bakti sosial bibir sumbing dengan peningkatan wawasan di atas rata-rata sebanyak 10 $(18.5 \%)$ responden.

Tabel 6. Tabulasi silang peningkatan wawasan

\begin{tabular}{cccc}
\hline & $95 \% \mathrm{CI}$ & $t$ & Sig. \\
\hline Pre test - Post test & $-13.555--3.037$ & -3.164 & 0.003 \\
\hline
\end{tabular}

Berdasarkan hasil analisis menggunakan paired sampel t-test menunjukkan bahwa nilai sig. 0.003 , karena nilai sig $0.003<$ nilai probabilitas 0.05 maka dapat disimpulkan bahwa terdapat perbedaan antara nilai skor pre test dan post test yang artinya ada pengaruh diselenggarakannya webinar utilisasi bakti sosial bibir sumbing dan lelangit di daerah terpencil dalam meningkatkan pengetahuan peserta webinar.

Bakti sosial atau lebih dikenal dengan baksos merupakan salah satu kegiatan hasil dari rasa kemanusiaan yang timbul untuk sesama (Mutmainnah et al., 2020). Ditinjau dari aspek utilisasi baksos bibir sumbing dan lelangit maka standar yang disusun meliputi standar administrasi, standar SDM, standar kelengkapan fasilitas, standar peralatan dan bahan serta standar prosedur tata kelola baksos mulai dari perencanaan hingga laporan akhir kegiatan. Sumber Daya Manusia (SDM) memiliki peran yang besar dalam terlaksananya kegiatan bakti sosial bibir sumbing dan lelangit. Beberapa SDM yang paling berperan diantaranya dokter yang bertindak sebagai operator dan asisten operator saat baksos. Dokter operator adalah dokter gigi spesialis bedah mulut dan maksilofasial atau dokter spesialis bedah yang memiliki SIP dan mendapat surat tugas dan didaftarkan ke Dinas Kesehatan untuk mengikuti kegiatan bakti social, sedangkan dokter asisten operator adalah dokter gigi program pendidikan dokter gigi spesalis 
bedah mulut dan maksilofasial yang memiliki STR-P/SIP-P dan mendapatkan surat tugas untuk mengikuti kegiatan bakti sosial.

Dari hasil penelitian disebutkan bahwa peningkatan wawasan peserta webinar lebih tinggi pada individu yang berusia di atas 26 tahun. Usia di atas 26 tahun merupakan usia produktif yang paling berperan dan memiliki aktivitas yang padat serta memiliki kemampuan kognitif yang baik. Sehingga, pada usia ini memiliki pengaruh terhadap tingkat pengetahuan. Semakin bertambah usia juga akan semakin berkembang pula daya tangkap dan pola pikirnya, sehingga pengetahuan yang diperolehnya semakin baik. Selain itu, pada usia tersebut juga seseorang memiliki pengalaman dan kemampuan yang luas untuk beraktifitas yang tentunya akan menunjang pengetahuannya dalam segala hal(Suwaryo \& Yuwono, 2017).

Perbedaan jenis kelamin dapat membentuk persepsi yang berbeda sehingga mempengaruhi sikap dan pengetahuan yang berbeda juga antara laki-laki dan perempuan. Lakilaki dan perempuan memliki tindakan yang berbeda dalam membuat keputusan etis dan kognitif. Pendekatan sosial jenis kelamin dan literature dari Gillgan (1982) dalam Carter (2011) menyebutkan bahwa laki-laki dan perempuan mengevaluasi dilema etis secara berbeda. Berdasarkan pendekatan tersebut, pria lebih cenderung fokus pada kesuksesan secara kompetitif dan cenderung mengabaikan aturan demi kesuksesan. Hal ini tidak berbanding lurus dengan kemampuan kognitif seseorang. Sedangkan, perempuan lebih berorientasi pada tugas dan kurang kompetitif

Dari hasil analisa menyebutkan bahwa responden berjenis kelamin laki-laki memiliki peningkatan wawasan yang lebih tinggi daripada perempuan, hal tersebut mungkin disebabkan oleh hakikat individu laki-laki yang pekerja keras dan aktif dalam berbagai kegiatan sehingga akan mempengaruhi tingkat pengetahuannya. Pernyataan tersebut relevan terhadap hasil penelitian yang menunjukkan bahwa responden yang sudah pernah mengikuti baksos bibir sumbing sebelumnya, memiliki peningkaan wawasan yang lebih tinggi daripada responden yang belum pernah mengikuti. Perubahan sikap dan peningkatan wawasan lebih terlihat pada responden yang sudah mengikuti baksos sebelumnya, hal tersebut dikarenakan bahwa semakin banyak pengalaman yang didapat maka semakin mudah dan banyak menerima informasi, sehingga berdampak pada tingkat wawasan yang dimiliki.

Hasil analisa juga menyebutkan bahwa responden yang juga bekerja sebagai dokter gigi praktisi memiliki peningkatan wawasan yang lebih tinggi daripada pekerjaan yang lain. Pekerjaan dapat berpengaruh pada pembentukan perilaku individu dan pengalaman pekerjaan yang diperoleh dapat membantu dalam melaksanakan tugas yang diberikan. Sebagai seorang dokter gigi praktisi, beban serta kesibukan yang dialami berbeda dengan pekerjaan sebagai dokter gigi yang sekaligus menjadi PNS dan tentara. Dokter gigi praktisi cenderung memiliki kesempatan lebih banyak untuk membentuk pola perilaku dan mencari pengalaman lebih besar daripada profesi yang lain sehingga hal tersebut dapat mempengaruhi tingkat wawasannya.

Tingkat pengetahuan dan wawasan responden dapat dipengaruhi oleh Pendidikan, umur, jenis kelamin, pekerjaan, budaya, pengalaman dan jenis pekerjaan(Riawati, 2019). Peningkatan wawasan mengenai aspek utilisasi baksos bibir sumbing dan lelangit diperlukan untuk keberhasilan kegiatan tersebut, sehingga dapat mencapai Sustainable Development Goals (SDGs), khususnya pada poin Kehidupan Sehat dan Sejahtera Menjamin Kehidupan yang Sehat dan Meningkatkan Kesejahteraan Seluruh Penduduk Semua Usia.

\section{KESIMPULAN}

Penyelenggaraan sosialisasi melalui webinar mengenai utilisasi bakti sosial bibir sumbing dan lelangit di daerah terpencil memberikan pengaruh terhadap peningkatan wawasan residen PPDGS BMM. Peningkatan wawasan mengenai utilisasi baksos bibir sumbing dan lelangit diharapkan dapat direalisasikan untuk keberhasilan pelaksanaan baksos didaerah terpencil. 


\section{DAFTAR PUSTAKA}

Carter, W. (2011). Disaster Manegement: A Disaster Manager's Handbook. Manila: ADB, 1-204.

Ciasullo, M. V., Orciuoli, F., Douglas, A. \& Palumbo, R. (2021). Putting Health 4.0 at the service of Society 5.0: Exploratory insights from a pilot study. Socio-Economic Planning Sciences, December 2020, 101163. https://doi.org/10.1016/j.seps.2021.101163

Kemenkes RI. (2018). InfoDATIN: Kelainan bawaan. Pusat Data Dan Informasi Kementerian Kesehatan RI, 1-6.

Kemenkes RI. (2019). Keputusan Menteri Kesehatan Republik Indonesia Nomor HK.01.07/Menkes/321/2019: Pedoman Nasional Pelayanan kedokteran Tata Laksana Bibir Sumbing dan lelangit. Kementerian Kesehatan Republik Indonesia.

Kemenristekdikti. (2015). Peraturan Menteri Riset, Teknologi, dan Pendidikan Tinggi Republik Indonesia nomor 44 Tahun 2015: Standar Nasional Pendidikan Tinggi. In Berita Negara Republik Indonesia (p. No. 1952).

Mutmainnah, M., Widodo, A., Dimyati, A., Dhiani, H. \& Wardani, S. (2020). Aplikasi Social Responsibility: Kegiatan Bakti Sosial Dalam Masa Pandemi Covid-19 Di Kelurahan Kukusan Rt 06 Rw 05 Kecamatan Beji Kota Depok Jawa Barat. Dedikasi Pkm, 1(3), 33.

Novalia, V., Siregar, S. \& Fathiah. (2021). Sosialisasi New Normal, Dampak Covid-19 dan Bakti Sosial; Hadapi New Normal Dengan Strategi Pembelajaran Digital di Gampong Lhokcut, Kecamatan Sawang, Kabupaten Aceh Utara. Jurnal Pengabdian Masyarakat (Kesehatan), 3(1).

Riawati, D. (2019). Hubungan Antara Usia Dengan Deteksi Dini Kanker Serviks Metode Iva. Avicenna: Journal Of Health Research, 2(2), 104-110.

Suwaryo, P. \& Yuwono, P. (2017). Faktor-Faktor Yang Mempengaruhi Tingkat Pengetahuan Masyarakat dalam Mitigasi Bencana Alam Tanah Longsor.

Tollefson, T. T., Shaye, D., Durbin-Johnson, B., Mehdezadeh, O., Mahomva, L. \& Chidzonga, M. (2015). Cleft lip-cleft palate in Zimbabwe: Estimating the distribution of the surgical burden of disease using geographic information systems. The Laryngoscope, 125(S1), S1-S14. https://doi.org/10.1002/LARY.24747 


\section{Halaman Ini Dikosongkan}

